\title{
Endoplasmic Reticulum Stress in Hearing Loss
}

\author{
Yanfei Wang ${ }^{1,2}$ (D), Xiangguo Liu ${ }^{2}$ and Zhigang $\mathrm{Xu}^{1,2, *}$ \\ 1 Shenzhen Research Institute of Shandong University, Shenzhen 518057, Guangdong, China; \\ wang_yf@sdu.edu.cn \\ 2 Shandong Provincial Key Laboratory of Animal Cells and Developmental Biology, \\ Shandong University School of Life Sciences, Jinan 250100, Shandong, China; xgliu@sdu.edu.cn \\ * Correspondence: xuzg@sdu.edu.cn; Tel./Fax: +86-531-8836-2647
}

Received: 16 October 2017; Accepted: 30 October 2017; Published: 1 November 2017

\begin{abstract}
The endoplasmic reticulum (ER) plays important roles in coordinating protein biosynthesis and secretion in the cell. Accumulation of misfolded and/or unfolded proteins in the ER causes ER stress and the so-called unfolded protein response (UPR). The UPR alleviates ER stress through blocking protein synthesis and activating expression of chaperone genes, whereas prolonged UPR could induce cell death. Recent research has showed that ER stress and UPR are involved in hearing loss. Accordingly, animal experiments showed that chemical chaperones or ER stress inducers alleviate environment-related hearing loss, whereas ER stress inhibitor has been used to treat certain types of hereditary deafness. Further investigations are needed to fully understand the detailed mechanisms of how ER stress contributes to the loss of auditory function, which will help us to eventually develop ER-stress-related treatment of various types of deafness.
\end{abstract}

Keywords: endoplasmic reticulum stress; unfolded protein response; hearing loss; hair cells

\section{Introduction}

The endoplasmic reticulum (ER) is a membranous tubular intracellular organelle that plays important roles in protein and lipid biosynthesis as well as calcium storage. Transmembrane and secretory proteins are synthesized and folded in the ER before being transported to their destinations. Unfolded or misfolded proteins are folded into correct conformations with the help of ER-residing chaperons such as Bip/GRP78, or subjected to degradation by the proteasome-dependent ER-associated protein degradation (ERAD) pathway [1]. When there are too many unfolded or misfolded proteins accumulated in the ER, the ER becomes stressed and the so-called unfolded protein response (UPR) is activated [2-4]. The UPR aims to alleviate ER stress through blocking protein synthesis and activating the expression of chaperone genes, whereas prolonged UPR could induce cell death $[5,6]$.

At least three ER-stress-sensors are involved in UPR, the inositol-requiring enzyme $1 \alpha$ (IRE1 $\alpha)$, the PKR-like ER kinase (PERK), and the activating transcription factor $6 \alpha$ (ATF6 $\alpha$ ) (Figure 1). All of the three sensors are transmembrane proteins normally associated with Bip/GRP78 at the ER. Unfolded or misfolded proteins that have accumulated in the ER sequester BiP from the ER stress sensors and activate UPR through different mechanisms: (1) After oligomerization and trans-autophosphorylation, IRE1 $\alpha$ obtains endoribonuclease activity and induces the unconventional splicing of XBP1 mRNA into XBP1s [7-9]. XBP1s encodes an active transcription factor whose target genes are involved in ER membrane biogenesis as well as ER protein folding $[10,11]$. (2) PERK, which is structurally related to IRE1 $\alpha$, gains its kinase activity after oligomerization and trans-autophosphorylation. Activated PERK phosphorylates the $\alpha$ subunit of eukaryotic translational initiation factor $2 \alpha(\mathrm{eIF} 2 \alpha)$ at Ser51 [12,13]. The phosphorylation of eIF2 $\alpha$ attenuates the global protein synthesis, but enhances the translation of activating transcription factor 4 (ATF4) whose mRNA contains internal ribosomal entry sites (IRES) [14]. 
ATF4 then induces expression of genes that are involved in ER function, reactive oxygen species (ROS) production, as well as cell death [15]. Among the ATF4-target genes is C/EBP homologous protein (CHOP/GADD153), whose most well-known function is the induction of cell death [14,16]. (3) ATF6 $\alpha$ is a type-two transmembrane basic leucine zipper (bZIP) transcription factor. Upon release from $\mathrm{BiP}, \mathrm{ATF} 6 \alpha$ moves from the ER to the Golgi apparatus, where the cleavage by serine protease site- 1 (S1P) and metalloprotease site-2 (S2P) releases the transcription-activating form of ATF6 [17-19]. The activated ATF6 induces the expression of genes encoding several ER chaperons as well as XBP1 and CHOP [20].

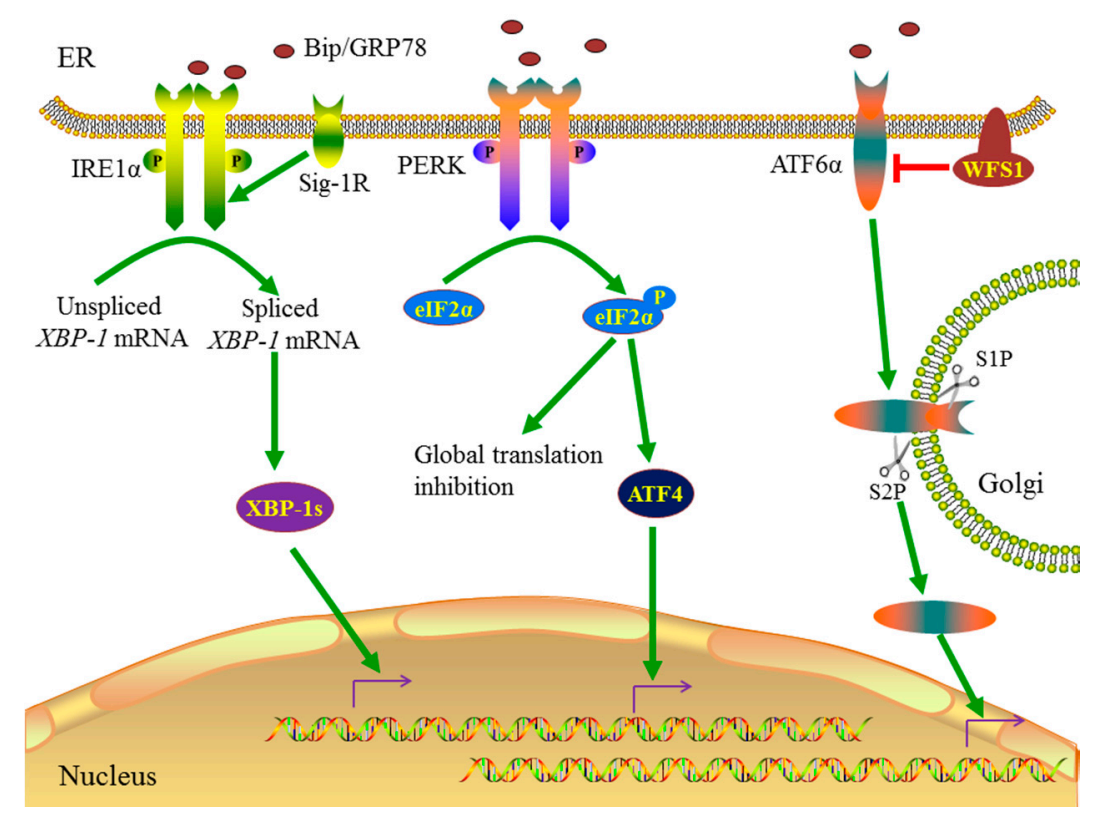

Figure 1. Endoplasmic reticulum (ER) stress and unfolded protein response (UPR) in mammals. See main text for details.

Germline deletion of Ire1 $\alpha$ or Xbp 1 in mice is embryonically lethal, suggesting that the IRE1 $\alpha /$ XBP1 pathway is indispensable for embryonic development $[21,22]$. PERK deficiency in mice results in diabetes mellitus, skeletal dysplasias, and growth retardation $[23,24]$, whereas ATF4 deficiency in mice causes microphthalmia [25,26], anemia [27], and bone angiogenesis deficits [28]. Interestingly, ATF4 deficiency protects mice from ER-stress-induced tissue damage [29-31]. Similar protective phenotypes were also observed in CHOP deficient mice [16,32,33]. Finally, mice lacking ATF6 $\alpha$ are viable without significant abnormalities, but are exquisitely sensitive to ER stress [34,35].

ER stress is implicated in many diseases, including multiple types of neural diseases $[36,37]$. More and more evidence suggests that ER stress plays an important role in hearing loss. In the following part, we will discuss the role of ER stress and UPR in different types of deafness.

\section{ER Stress and Drug-Induced Hearing Loss}

The use of ototoxic drugs causes drug-induced hearing loss (DIHL) [38]. Animal and cell experiments have showed that ER stress is involved in hearing loss induced by ototoxic drugs such as aminoglycosides, 3-nitropropionic acid (3-NP), N-acetyl-para-aminophenol (APAP), and $N$-acetyl-p-benzoquinoneimine (NAPQI) [39-41]. Furthermore, perilymphatic perfusion of the ER-stress-activator tunicamycin results in profound hearing loss in rats [42]. In the cochlea, ER stress affects different cell types including hair cells (HCs), spiral ganglion cells (SGCs), and fibrocytes, depending on the chemicals used [39,41,42]. For example, tunicamycin induces ER stress in HCs and SGCs; in contrast, gentamicin induces ER stress in SGCs but not in HCs [41]. 
Different ototoxic drugs activate different UPR pathways. For example, 3-NP treatment causes increased expression of ATF4 and CHOP, resulting in the apoptosis of lateral wall fibrocytes [39]. In cultured cells derived from mouse organ of Corti (HEI-OC1), APAP or NAPQI treatment alters eIF2 $\alpha$ phosphorylation as well as CHOP expression independent of ATF4 activation, and results in cell death [40]. In contrast, aminoglycosides activate all three UPR pathways in cultured HEK293 cells [41]. Interestingly, XBP1 could alleviate aminoglycoside-induced ER stress and hearing loss. Aminoglycoside-induced UPR was compromised and more severe hearing loss was observed in $\mathrm{Xbp}^{+/-}$mice compared with wild-type mice [41]. Moreover, treatment of the chemical chaperone tauroursodeoxycholic acid (TUDCA) attenuated aminoglycoside-induced hearing loss in $X b p 1^{+/-}$mice, further supporting the hypothesis that UPR could protect drug-induced hearing loss [41].

\section{ER Stress and Noise-Induced Hearing Loss}

Prolonged exposure to high-intensity noise causes permanent hearing threshold shift called noise-induced hearing loss (NIHL). Research suggests that both HCs and SGNs are sensitive to noise damage [43]. During NIHL, the protein level of Bip/GRP78, Caspase-12, and CHOP/GADD153 is elevated, suggesting a protective effect of UPR [44,45]. The ER-residing chaperones Sigma-1 receptors (Sig-1Rs) are transcriptionally upregulated by the PERK/eIF2 $\alpha /$ ATF4 pathway, and could ameliorate cell death signaling [46,47]. Under ER Stress, Sig-1Rs stabilize IRE1 $\alpha$ and activate the IRE1 $\alpha /$ XBP1s pathway [48,49]. Meanwhile, Sig-1Rs inhibit CHOP expression and decrease cellular toxicity [49]. Sig-1R agonist cutamesine (SA4503) significantly reduces hearing threshold shifts and cell death in response to intense noise, whereas it has no effect on age-related hearing loss [50]. At present, the detailed role of ER stress and UPR in NIHL awaits further investigation.

\section{ER Stress and Age-Related Hearing Loss}

Age-related hearing loss (ARHL), also referred to as presbycusis, is characterized by an elevation in hearing thresholds during aging. In the cochlea of aged mice, the expression of Bip/GRP78 is reduced, whereas the expression of CHOP is increased, suggesting that the UPR pathway is impaired and the cell death pathway is activated [51]. Consistently, the cleavage of caspase-3, caspase-9, but not caspase-12, is increased in the aged cochlea [51].

Geranylgeranylacetone (GGA) is a widely-used HSP70 inducer; however, recently it was shown that GGA could also elicit UPR [52,53]. Oral uptake of GGA attenuates ARHL in mice [54]. Moreover, GGA has also been shown to ameliorate 3-NP-induced hearing loss and NIHL [55,56]. The mechanism by which GGA protects auditory function has been attributed to its induction of HSP70, whereas the role of UPR in this process has not been examined and awaits further investigation.

\section{ER Stress and Hereditary Hearing Loss}

Gene mutations that affect ER stress and UPR have been shown to cause hereditary hearing loss (HHL). The most well-known deafness condition associated with impaired ER stress is caused by mutations in genes encoding WFS1 and connexins [57-59]. Recently, it was shown that impaired ER stress is also involved in Usher (USH) syndrome [60,61].

\subsection{WFS1 and ER Stress}

WFS1, also known as wolframin, is an ER transmembrane protein that acts as a negative regulator in UPR $[62,63]$. The expression of WFS1 is induced by ER stress through IRE1 $\alpha$ and PERK, whereas WFS1 recruits ATF6 $\alpha$ to the proteasome for degradation, hence providing a negative feedback loop of UPR $[63,64]$. WFS1 also interacts with the ER-localized $\mathrm{Na}^{+} / \mathrm{K}^{+}$ATPase $\beta 1$ subunit (ATP1B1), vacuolar-type $\mathrm{H}^{+}$-ATPase V1A subunit (ATP6V1A), and calmodulin (CaM) [65-67].

Homozygous or compound heterozygous mutations in the human WFS1 gene cause Wolfram syndrome (WS), which is characterized by diabetes insipidus, diabetes mellitus, optic atrophy, deafness, and psychiatric illness $[57,58]$. WFS1 gene mutations in WS patients cause a complete absence of WFS1 
protein by nonsense-mediated mRNA decay (NMD), or instability and a strongly reduced half-life of WFS1 protein $[68,69]$. In other words, WS-associated WFS1 mutations lead to loss of function of WFS1. Consistently, $W f s 1$ gene knockdown in cultured cells or $W f s 1$ gene disruption in mice caused elevated UPR and increased ER-stress-induced apoptosis [63,70-72]. It is worth noticing that Wfs1 disruption has different effects on different tissues in mice. In $W f s 1^{-/-}$mice, all three UPR pathways are activated in pancreatic cells, whereas only the IRE1 $\alpha$ pathway is activated in the retina, and no ER stress is activated in other tissues examined such as the heart, skeletal muscle, and brown adipose tissue [71,72]. WFS1 is widely expressed in multiple cell types in the inner ear, including HCs, SGCs, various supporting cells (SCs), and lateral wall fibrocytes [73]. ER stress activation in the $\mathrm{Wfs}_{\mathrm{s}}{ }^{-/-}$inner ear has not been reported yet.

Heterozygous mutations in the WFS1 gene are identified in patients with WS [74] or nonsyndromic disease such as nonsyndromic dominant deafness DFNA6/14/38, which is one of the few low-frequency sensorineural hearing impairment (LFSNHI) [75,76]. Research suggested that most heterozygous WFS1 mutations are likely small non-inactivating mutations [74,77]. Interestingly, nine out of ten LFSNHI-associated WFS1 mutations affect the C-terminal protein domain of WFS1 [77]. ER stress activation of LFSNHI-associated WFS1 mutations have not been reported at present. Nevertheless, WS- or diabetes-associated heterozygous WFS1 mutations have been shown to cause enhanced ER stress through ATF6 $\alpha$ activation in transfected cells [78-80].

\subsection{Connexins and ER Stress}

Gap junctions are clustered channels that connect the cytoplasm of adjacent cells. By providing direct intercellular communication, gap junctions play important roles in the exchange of ions, second messengers, and metabolites between adjacent cells [81]. In vertebrates, gap junction proteins known as connexins are encoded by nearly 20 genes [82]. Mutations in connexin genes have been shown to associate with various types of disease, including peripheral neuropathy, skin disease, cataracts, and hearing loss [59]. Mutations in GJB2, which encodes for connexin 26 (Cx26), contribute to $\sim 50 \%$ of autosomal recessive nonsyndromic hearing loss [83-88]. Other connexins that might be involved in hearing loss include Cx30 (GJB6) [89,90], Cx31 (GJB3) [91], and Cx29 (GJC3) [92].

There is evidence that supports a possible link between ER stress and connexin expression and/or function. Treatment of cells with ER stress inducers resulted in decreased expression of connexins such as $\mathrm{C} \times 36$ and $\mathrm{C} \times 43$, as well as reduced gap junctional intercellular communication $[93,94]$. Selective down-regulation of gap junction proteins might help to alleviate the burden of ER and prevent the transmission of 'stress' signals to adjacent cells, hence providing an important protective mechanism under ER stress [93]. On the other hand, mutations in connexin genes have been shown to induce ER stress. For example, skin-disease-associated Cx31 mutants were shown to induce all three UPR pathways in transfected cells [95]. ER stress is also activated in cataract-associated Cx50 mutant mouse lenses [96,97]. Interestingly, different UPR pathways are activated by different Cx50 mutations. In Cx50G22R or Cx50S50P mutant mice, the IRE1 $\alpha$-XBP1 pathway is activated, while PERK-eIF2 $\alpha$-ATF4 and ATF6 $\alpha$ pathways are largely unaffected [96]. In contrast, in Cx50D47A mutant mice, the PERK-eIF2 $\alpha$-ATF4 pathway is activated, while the IRE1 $\alpha$-XBP1 and ATF6 $\alpha$ pathways are not activated [97].

ER stress might also play a role in connexin-mutation-associated hearing loss. Several deafnessassociated Cx26, Cx29, Cx30, and Cx31 mutants have been shown to be trapped in the ER and are unable to transport to the plasma membrane in transfected cells [98-102]. Moreover, Bip/GRP78 is upregulated in Cx31R180X- or Cx31E183K-overexpressed cells, suggesting that ER stress is elevated by these Cx31 mutations [101]. It is worth noting that not all deafness-associated connexin mutants induce ER stress or are trapped in the ER. For example, deafness-associated Cx31(66delD) does not induce ER stress in transfected cells, suggesting that a mechanism other than ER stress is involved in these specific mutants [95]. 


\subsection{USH Proteins and ER Stress}

USH proteins are a group of proteins whose dysfunctions cause Usher syndrome, the most frequent form of inherited sensory deaf-blindness [103]. USH is clinically classified into three types, namely USH1, USH2, and USH3, and more than ten USH proteins have been identified so far [104]. Mutations in the USH genes are also associated with nonsyndromic hearing loss [104]. USH proteins are expressed in HCs of the inner ear, especially on the stereocilia and at the ribbon synapses, where they bind to one another and form multiprotein complexes [104]. At the cellular level, most USH gene mutations cause stereocilia and/or ribbon synapse deficits, and eventually result in hair cell death. However, the proximal cause of hair cell death remains elusive.

The first clue came from the finding that three CLRN1 (USH3A) pathogenic mutant proteins were mislocalized in the ER instead of on the plasma membrane in transfected cells [105]. Similarly, USH proteins CDH23 (USH1D), harmonin (USH1C) and Myo7a (USH1B) were shown to preassemble into a complex at the ER in zebrafish hair cells, and defects in any one of the three USH proteins disrupt the complex and induce ER stress that triggers apoptosis [60]. Thus ER stress might contribute to hair cell loss and provide a potential target for the treatment of Usher syndrome.

Recently, important progress was achieved using a mouse model erlong (erl) that harbors a point mutation (T208C) in Cdh23 gene. The erl mice suffered hearing loss through apoptosis beginning from postnatal day 27 (P27) [106]. Further investigation showed that the PERK-eIF2 $\alpha$-ATF4-CHOP pathway is activated in erl mice, which eventually causes apoptosis of OHCs [61]. Disruption of the Chop gene protects OHCs as well as auditory function in erl mice, further supporting the role of CHOP in ER stress-induced OHC apoptosis in erl mice [61]. Most importantly, treatment of erl mice with ER stress inhibitor Salubrinal (Sal) delays the progression of hearing loss and preserves OHCs [61]. Taken together, these data suggest that ER stress plays important roles in OHC loss and deafness in erl mice, and anti-ER stress drugs could serve an otoprotective purpose.

\section{Conclusions and Perspectives}

The role of ER stress and UPR in hearing loss is just starting to be appreciated. Several mechanisms have been proposed to contribute to DIHL, NIHL, and ARHL, including oxidative stress, calcium overload, inflammatory responses, and hereditary susceptibility [38,107-110]. Recent research has added ER stress and UPR to this list, although more details await further investigation (Table 1). Chemical chaperones or ER stress inducers have been shown to alleviate hearing loss, further confirming the protective role of ER stress in hearing. ER stress has also been shown to play a role in hereditary hearing loss (Table 2). WFS1 is a negative regulator in UPR, and WFS1 mutations result in elevated UPR and increase ER-stress-induced apoptosis, eventually causing hearing loss. Connexins and USH proteins are mostly transmembrane proteins that are important for hearing transduction. Dysfunctions of connexins or USH proteins might increase the burden of ER, hence resulting in ER stress that eventually leads to hearing loss.

Further investigation is needed to examine whether ER stress is also involved in hereditary hearing loss types other than the ones discussed above. More than 110 nonsyndromic deafness genes have been identified, which only represent a small portion of all deafness genes [111]. At present, WFS1 is the only ER stress regulator whose mutations are associated with hearing loss. As novel deafness genes are identified, more ER-stress-related deafness genes will emerge. Additionally, similar to connexins and USH proteins, many deafness genes encode membrane proteins or secretory proteins, whose malfunction might increase the burden of ER and cause ER stress.

Present studies suggest that the detailed role of ER stress might differ in various types of deafness. ER stress seems to play a protective role in environment-related hearing loss (DIHL, NIHL, and ARHL), but a destructive role has been shown in certain types of hereditary hearing loss. If this is true, ER-stress-based treatment of different types of deafness should be different. In line with this, chemical chaperones or ER-stress-inducers have been shown to alleviate environment-related hearing loss, whereas ER-stress-inhibitors have been used to treat some types of hereditary deafness. 
Furthermore, different UPR pathways might be activated even in the same categories of deafness, suggesting that the role of ER stress in hearing loss is complicated, and that tailored ER-stress-based treatments must be developed.

Table 1. Summary of the roles of ER stress in environment-related hearing loss.

\begin{tabular}{lcccc}
\hline Hearing loss & $\begin{array}{c}\text { Alteration in ER } \\
\text { Stress }\end{array}$ & Models & $\begin{array}{c}\text { ER Stress-Related } \\
\text { Treatment }\end{array}$ & References \\
\hline DIHL & ATF $4 \uparrow$, CHOP $\uparrow$ & Rat/guinea pig cochlea & GGA & {$[39,56]$} \\
3-NP & H-eIF $2 \uparrow \uparrow$, CHOP $\uparrow$ & HEI-OC1 cell & & {$[40]$} \\
APAP & p-eIF2 $\alpha \downarrow$, CHOP $\uparrow$ & HEI-OC1 cell & TUDCA & {$[40]$} \\
NAPQI & All 3 UPR pathways $\uparrow$ & HEK cell, mouse cochlea & TU1] \\
Aminoglycosides & Bip $\uparrow$, CHOP $\uparrow$ & Guinea pig/mouse cochlea & SA4503,GGA & {$[44,45,50,55]$} \\
\hline NIHL & Bip $\downarrow$, CHOP $\uparrow$ & Mouse cochlea & GGA & {$[51,54]$} \\
\hline ARHL & & & &
\end{tabular}

Table 2. Summary of the roles of ER stress in hereditary hearing loss.

\begin{tabular}{|c|c|c|c|c|}
\hline Deafness Gene & $\begin{array}{c}\text { Alteration in ER } \\
\text { Stress }\end{array}$ & Models & $\begin{array}{c}\text { ER Stress-Related } \\
\text { Treatment }\end{array}$ & References \\
\hline \multirow{4}{*}{ WFS1 } & ATF6 $\alpha$ pathway $\uparrow$ & Knockdown cells & & {$[63,64]$} \\
\hline & All 3 UPR pathways $\uparrow$ & Knockout mouse pancreas & & {$[64,71]$} \\
\hline & IRE $1 \alpha$ pathway $\uparrow$ & Knockout mouse retina & & [72] \\
\hline & ATF6 $\alpha$ pathway $\uparrow$ & Mutant overexpressed cells & & [78-80] \\
\hline \multirow[b]{2}{*}{ GJB3 } & All 3 UPR pathways $\uparrow$ & Mutant overexpressed cells * & & [95] \\
\hline & Bip $\uparrow$ & Mutant overexpressed cells & & {$[101]$} \\
\hline $\mathrm{CDH} 23$ & PERK pathway $\uparrow$ & Mutant mouse cochlea & Salubrinal & [61] \\
\hline
\end{tabular}

Acknowledgments: Our laboratory is supported by grants from the National Natural Science Foundation of China (31371355) and Innovation Commission of Shenzhen Municipality (JCYJ20160331174108379).

Conflicts of Interest: The authors declare no conflict of interest.

\section{References}

1. Bernasconi, R.; Molinari, M. ERAD and ERAD tuning: Disposal of cargo and of ERAD regulators from the mammalian ER. Curr. Opin. Cell Biol. 2011, 23, 176-183. [CrossRef] [PubMed]

2. Mori, K. Tripartite management of unfolded proteins in the endoplasmic reticulum. Cell 2000, 101, 451-454. [CrossRef]

3. Kaufman, R.J. Orchestrating the unfolded protein response in health and disease. J. Clin. Investig. 2002, 110, 1389-1398. [CrossRef] [PubMed]

4. Ron, D.; Walter, P. Signal integration in the endoplasmic reticulum unfolded protein response. Nat. Rev. Mol. Cell Biol. 2007, 8, 519-529. [CrossRef] [PubMed]

5. Sano, R.; Reed, J.C. ER stress-induced cell death mechanisms. Biochim. Biophys. Acta 2013, 1833, 3460-3470. [CrossRef] [PubMed]

6. Iurlaro, R.; Munoz-Pinedo, C. Cell death induced by endoplasmic reticulum stress. FEBS J. 2016, 283, 2640-2652. [CrossRef] [PubMed]

7. Yoshida, H.; Matsui, T.; Yamamoto, A.; Okada, T.; Mori, K. XBP1 mRNA is induced by ATF6 and spliced by IRE1 in response to ER stress to produce a highly active transcription factor. Cell 2001, 107, 881-891. [CrossRef]

8. Calfon, M.; Zeng, H.; Urano, F.; Till, J.H.; Hubbard, S.R.; Harding, H.P.; Clark, S.G.; Ron, D. IRE1 couples endoplasmic reticulum load to secretory capacity by processing the XBP-1 mRNA. Nature 2002, 415, 92-96. [CrossRef] [PubMed] 
9. Lee, K.; Tirasophon, W.; Shen, X.; Michalak, M.; Prywes, R.; Okada, T.; Yoshida, H.; Mori, K.; Kaufman, R.J. IRE1-mediated unconventional mRNA splicing and S2P-mediated ATF6 cleavage merge to regulate XBP1 in signaling the unfolded protein response. Genes Dev. 2002, 16, 452-466. [CrossRef] [PubMed]

10. Lee, A.H.; Iwakoshi, N.N.; Glimcher, L.H. XBP-1 regulates a subset of endoplasmic reticulum resident chaperone genes in the unfolded protein response. Mol. Cell. Biol. 2003, 23, 7448-7459. [CrossRef] [PubMed]

11. Acosta-Alvear, D.; Zhou, Y.; Blais, A.; Tsikitis, M.; Lents, N.H.; Arias, C.; Lennon, C.J.; Kluger, Y.; Dynlacht, B.D. XBP1 controls diverse cell type- and condition-specific transcriptional regulatory networks. Mol. Cell 2007, 27, 53-66. [CrossRef] [PubMed]

12. Shi, Y.; Vattem, K.M.; Sood, R.; An, J.; Liang, J.; Stramm, L.; Wek, R.C. Identification and characterization of pancreatic eukaryotic initiation factor $2 \alpha$-subunit kinase, PEK, involved in translational control. Mol. Cell. Biol. 1998, 18, 7499-7509. [CrossRef] [PubMed]

13. Harding, H.P.; Zhang, Y.; Ron, D. Protein translation and folding are coupled by an endoplasmic-reticulumresident kinase. Nature 1999, 397, 271-274. [PubMed]

14. Harding, H.P.; Novoa, I.; Zhang, Y.; Zeng, H.; Wek, R.; Schapira, M.; Ron, D. Regulated translation initiation controls stress-induced gene expression in mammalian cells. Mol. Cell 2000, 6, 1099-1108. [CrossRef]

15. Harding, H.P.; Zhang, Y.; Zeng, H.; Novoa, I.; Lu, P.D.; Calfon, M.; Sadri, N.; Yun, C.; Popko, B.; Paules, R.; et al. An integrated stress response regulates amino acid metabolism and resistance to oxidative stress. Mol. Cell 2003, 11, 619-633. [CrossRef]

16. Marciniak, S.J.; Yun, C.Y.; Oyadomari, S.; Novoa, I.; Zhang, Y.; Jungreis, R.; Nagata, K.; Harding, H.P.; Ron, D. $\mathrm{CHOP}$ induces death by promoting protein synthesis and oxidation in the stressed endoplasmic reticulum. Genes Dev. 2004, 18, 3066-3077. [CrossRef] [PubMed]

17. Ye, J.; Rawson, R.B.; Komuro, R.; Chen, X.; Dave, U.P.; Prywes, R.; Brown, M.S.; Goldstein, J.L. ER stress induces cleavage of membrane-bound ATF6 by the same proteases that process SREBPS. Mol. Cell 2000, 6, 1355-1364. [CrossRef]

18. Shen, J.; Chen, X.; Hendershot, L.; Prywes, R. ER stress regulation of ATF6 localization by dissociation of BIP/GRP78 binding and unmasking of golgi localization signals. Dev. Cell 2002, 3, 99-111. [CrossRef]

19. Schindler, A.J.; Schekman, R. In vitro reconstitution of ER-stress induced ATF6 transport in COPII vesicles. Proc. Natl. Acad. Sci. USA 2009, 106, 17775-17780. [CrossRef] [PubMed]

20. Yoshida, H.; Okada, T.; Haze, K.; Yanagi, H.; Yura, T.; Negishi, M.; Mori, K. ATF6 activated by proteolysis binds in the presence of NF-Y (CBF) directly to the cis-acting element responsible for the mammalian unfolded protein response. Mol. Cell. Biol. 2000, 20, 6755-6767. [CrossRef] [PubMed]

21. Reimold, A.M.; Etkin, A.; Clauss, I.; Perkins, A.; Friend, D.S.; Zhang, J.; Horton, H.F.; Scott, A.; Orkin, S.H.; Byrne, M.C.; et al. An essential role in liver development for transcription factor XBP-1. Genes Dev. 2000, 14, 152-157. [PubMed]

22. Zhang, K.; Wong, H.N.; Song, B.; Miller, C.N.; Scheuner, D.; Kaufman, R.J. The unfolded protein response sensor IRE1 $\alpha$ is required at 2 distinct steps in b cell lymphopoiesis. J. Clin. Investig. 2005, 115, 268-281. [CrossRef] [PubMed]

23. Harding, H.P.; Zeng, H.; Zhang, Y.; Jungries, R.; Chung, P.; Plesken, H.; Sabatini, D.D.; Ron, D. Diabetes mellitus and exocrine pancreatic dysfunction in perk-/- mice reveals a role for translational control in secretory cell survival. Mol. Cell 2001, 7, 1153-1163. [CrossRef]

24. Zhang, P.; McGrath, B.; Li, S.; Frank, A.; Zambito, F.; Reinert, J.; Gannon, M.; Ma, K.; McNaughton, K.; Cavener, D.R. The perk eukaryotic initiation factor $2 \alpha$ kinase is required for the development of the skeletal system, postnatal growth, and the function and viability of the pancreas. Mol. Cell. Biol. 2002, 22, 3864-3874. [CrossRef] [PubMed]

25. Tanaka, T.; Tsujimura, T.; Takeda, K.; Sugihara, A.; Maekawa, A.; Terada, N.; Yoshida, N.; Akira, S. Targeted disruption of ATF4 discloses its essential role in the formation of eye lens fibres. Genes Cells 1998, 3, 801-810. [CrossRef] [PubMed]

26. Hettmann, T.; Barton, K.; Leiden, J.M. Microphthalmia due to p53-mediated apoptosis of anterior lens epithelial cells in mice lacking the CREB-2 transcription factor. Dev. Biol. 2000, 222, 110-123. [CrossRef] [PubMed]

27. Masuoka, H.C.; Townes, T.M. Targeted disruption of the activating transcription factor 4 gene results in severe fetal anemia in mice. Blood 2002, 99, 736-745. [CrossRef] [PubMed] 
28. Zhu, K.; Jiao, H.; Li, S.; Cao, H.; Galson, D.L.; Zhao, Z.; Zhao, X.; Lai, Y.; Fan, J.; Im, H.J.; et al. ATF4 promotes bone angiogenesis by increasing vegf expression and release in the bone environment. J. Bone Miner. Res. 2013, 28, 1870-1884. [CrossRef] [PubMed]

29. Li, H.; Meng, Q.; Xiao, F.; Chen, S.; Du, Y.; Yu, J.; Wang, C.; Guo, F. ATF4 deficiency protects mice from high-carbohydrate-diet-induced liver steatosis. Biochem. J. 2011, 438, 283-289. [CrossRef] [PubMed]

30. Ebert, S.M.; Dyle, M.C.; Kunkel, S.D.; Bullard, S.A.; Bongers, K.S.; Fox, D.K.; Dierdorff, J.M.; Foster, E.D.; Adams, C.M. Stress-induced skeletal muscle GADD45a expression reprograms myonuclei and causes muscle atrophy. J. Biol. Chem. 2012, 287, 27290-27301. [CrossRef] [PubMed]

31. Xiao, G.; Zhang, T.; Yu, S.; Lee, S.; Calabuig-Navarro, V.; Yamauchi, J.; Ringquist, S.; Dong, H.H. ATF4 protein deficiency protects against high fructose-induced hypertriglyceridemia in mice. J. Biol. Chem. 2013, 288, 25350-25361. [CrossRef] [PubMed]

32. Malhotra, J.D.; Miao, H.; Zhang, K.; Wolfson, A.; Pennathur, S.; Pipe, S.W.; Kaufman, R.J. Antioxidants reduce endoplasmic reticulum stress and improve protein secretion. Proc. Natl. Acad. Sci. USA 2008, 105, 18525-18530. [CrossRef] [PubMed]

33. Song, B.; Scheuner, D.; Ron, D.; Pennathur, S.; Kaufman, R.J. Chop deletion reduces oxidative stress, improves $\beta$ cell function, and promotes cell survival in multiple mouse models of diabetes. J. Clin. Investig. 2008, 118, 3378-3389. [CrossRef] [PubMed]

34. Wu, J.; Rutkowski, D.T.; Dubois, M.; Swathirajan, J.; Saunders, T.; Wang, J.; Song, B.; Yau, G.D.; Kaufman, R.J. ATF6 $\alpha$ optimizes long-term endoplasmic reticulum function to protect cells from chronic stress. Dev. Cell 2007, 13, 351-364. [CrossRef] [PubMed]

35. Yamamoto, K.; Takahara, K.; Oyadomari, S.; Okada, T.; Sato, T.; Harada, A.; Mori, K. Induction of liver steatosis and lipid droplet formation in ATF6 $\alpha$-knockout mice burdened with pharmacological endoplasmic reticulum stress. Mol. Biol. Cell 2010, 21, 2975-2986. [CrossRef] [PubMed]

36. Li, S.; Yang, L.; Selzer, M.E.; Hu, Y. Neuronal endoplasmic reticulum stress in axon injury and neurodegeneration. Ann. Neurol. 2013, 74, 768-777. [CrossRef] [PubMed]

37. Hetz, C.; Saxena, S. ER stress and the unfolded protein response in neurodegeneration. Nat. Rev. Neurol. 2017, 13, 477-491. [CrossRef] [PubMed]

38. Lanvers-Kaminsky, C.; Zehnhoff-Dinnesen, A.A.; Parfitt, R.; Ciarimboli, G. Drug-induced ototoxicity: Mechanisms, pharmacogenetics, and protective strategies. Clin. Pharmacol. Ther. 2017, 101, 491-500. [CrossRef] [PubMed]

39. Fujinami, Y.; Mutai, H.; Kamiya, K.; Mizutari, K.; Fujii, M.; Matsunaga, T. Enhanced expression of C/EBP homologous protein $(\mathrm{CHOP})$ precedes degeneration of fibrocytes in the lateral wall after acute cochlear mitochondrial dysfunction induced by 3-nitropropionic acid. Neurochem. Int. 2010, 56, 487-494. [CrossRef] [PubMed]

40. Kalinec, G.M.; Thein, P.; Parsa, A.; Yorgason, J.; Luxford, W.; Urrutia, R.; Kalinec, F. Acetaminophen and NAPQI are toxic to auditory cells via oxidative and endoplasmic reticulum stress-dependent pathways. Hear. Res. 2014, 313, 26-37. [CrossRef] [PubMed]

41. Oishi, N.; Duscha, S.; Boukari, H.; Meyer, M.; Xie, J.; Wei, G.; Schrepfer, T.; Roschitzki, B.; Boettger, E.C.; Schacht, J. XBP1 mitigates aminoglycoside-induced endoplasmic reticulum stress and neuronal cell death. Cell Death Dis. 2015, 6, e1763. [CrossRef] [PubMed]

42. Fujinami, Y.; Mutai, H.; Mizutari, K.; Nakagawa, S.; Matsunaga, T. A novel animal model of hearing loss caused by acute endoplasmic reticulum stress in the cochlea. J. Pharmacol. Sci. 2012, 118, 363-372. [CrossRef] [PubMed]

43. Liberman, M.C. Noise-induced hearing loss: Permanent versus temporary threshold shifts and the effects of hair cell versus neuronal degeneration. Adv. Exp. Med. Biol. 2016, 875, 1-7. [PubMed]

44. Xue, Q.H.; Chen, J.; Gong, S.S.; He, J.; Xie, J.; Chen, X.L. Role of caspase 12 in apoptosis of cochlea induced by intense noise in guinea pigs. Chin. J. Otorhinolaryngol. Head Neck Surg. 2009, 44, 154-159.

45. Xue, Q.; Li, C.; Chen, J.; Guo, H.; Li, D.; Wu, X. The protective effect of the endoplasmic reticulum stress-related factors BIP/GRP78 and CHOP/GADD153 on noise-induced hearing loss in guinea pigs. Noise Health 2016, 18, 247-255. [PubMed]

46. Hayashi, T.; Su, T.P. Sigma-1 receptor chaperones at the er-mitochondrion interface regulate $\mathrm{Ca}^{2+}$ signaling and cell survival. Cell 2007, 131, 596-610. [CrossRef] [PubMed] 
47. Mitsuda, T.; Omi, T.; Tanimukai, H.; Sakagami, Y.; Tagami, S.; Okochi, M.; Kudo, T.; Takeda, M. Sigma-1Rs are upregulated via PERK/EIF2 $\alpha /$ ATF4 pathway and execute protective function in ER stress. Biochem. Biophys. Res. Commun. 2011, 415, 519-525. [CrossRef] [PubMed]

48. Mori, T.; Hayashi, T.; Hayashi, E.; Su, T.P. Sigma-1 receptor chaperone at the ER-mitochondrion interface mediates the mitochondrion-ER-nucleus signaling for cellular survival. PLoS ONE 2013, 8, e76941. [CrossRef] [PubMed]

49. Alam, S.; Abdullah, C.S.; Aishwarya, R.; Orr, A.W.; Traylor, J.; Miriyala, S.; Panchatcharam, M.; Pattillo, C.B.; Bhuiyan, M.S. Sigmar1 regulates endoplasmic reticulum stress-induced C/EBP-homologous protein expression in cardiomyocytes. Biosci. Rep. 2017, 37, BSR20170898. [CrossRef] [PubMed]

50. Yamashita, D.; Sun, G.W.; Cui, Y.; Mita, S.; Otsuki, N.; Kanzaki, S.; Nibu, K.; Ogawa, K.; Matsunaga, T. Neuroprotective effects of cutamesine, a ligand of the sigma-1 receptor chaperone, against noise-induced hearing loss. J. Neurosci. Res. 2015, 93, 788-795. [CrossRef] [PubMed]

51. Wang, W.; Sun, Y.; Chen, S.; Zhou, X.; Wu, X.; Kong, W.; Kong, W. Impaired unfolded protein response in the degeneration of cochlea cells in a mouse model of age-related hearing loss. Exp. Gerontol. 2015, 70, 61-70. [CrossRef] [PubMed]

52. Endo, S.; Hiramatsu, N.; Hayakawa, K.; Okamura, M.; Kasai, A.; Tagawa, Y.; Sawada, N.; Yao, J.; Kitamura, M. Geranylgeranylacetone, an inducer of the 70-kda heat shock protein (HSP70), elicits unfolded protein response and coordinates cellular fate independently ofHSP70. Mol. Pharmacol. 2007, 72, 1337-1348. [CrossRef] [PubMed]

53. Hayakawa, K.; Hiramatsu, N.; Okamura, M.; Yao, J.; Paton, A.W.; Paton, J.C.; Kitamura, M. Blunted activation of NF- $\mathrm{kB}$ and Nf-kB-dependent gene expression by geranylgeranylacetone: Involvement of unfolded protein response. Biochem. Biophys. Res. Commun. 2008, 365, 47-53. [CrossRef] [PubMed]

54. Mikuriya, T.; Sugahara, K.; Sugimoto, K.; Fujimoto, M.; Takemoto, T.; Hashimoto, M.; Hirose, Y.; Shimogori, H.; Hayashida, N.; Inouye, S.; et al. Attenuation of progressive hearing loss in a model of age-related hearing loss by a heat shock protein inducer, geranylgeranylacetone. Brain Res. 2008, 1212, 9-17. [CrossRef] [PubMed]

55. Mikuriya, T.; Sugahara, K.; Takemoto, T.; Tanaka, K.; Takeno, K.; Shimogori, H.; Nakai, A.; Yamashita, H. Geranylgeranylacetone, a heat shock protein inducer, prevents acoustic injury in the guinea pig. Brain Res. 2005, 1065, 107-114. [CrossRef] [PubMed]

56. Kim, Y.H.; Song, J.J.; Kim, Y.C.; Park, K.T.; Lee, J.H.; Choi, J.M.; Lee, J.H.; Oh, S.H.; Chang, S.O. Geranylgeranylacetone ameliorates acute cochlear damage caused by 3-nitropropionic acid. Neurotoxicology 2010, 31, 317-325. [CrossRef] [PubMed]

57. Inoue, H.; Tanizawa, Y.; Wasson, J.; Behn, P.; Kalidas, K.; Bernal-Mizrachi, E.; Mueckler, M.; Marshall, H.; Donis-Keller, H.; Crock, P.; et al. A gene encoding a transmembrane protein is mutated in patients with diabetes mellitus and optic atrophy (wolfram syndrome). Nat. Genet. 1998, 20, 143-148. [CrossRef] [PubMed]

58. Strom, T.M.; Hortnagel, K.; Hofmann, S.; Gekeler, F.; Scharfe, C.; Rabl, W.; Gerbitz, K.D.; Meitinger, T. Diabetes insipidus, diabetes mellitus, optic atrophy and deafness (didmoad) caused by mutations in a novel gene (wolframin) coding for a predicted transmembrane protein. Hum. Mol. Genet. 1998, 7, 2021-2028. [CrossRef] [PubMed]

59. Srinivas, M.; Verselis, V.K.; White, T.W. Human diseases associated with connexin mutations. Biochim. Biophys. Acta 2017. [CrossRef] [PubMed]

60. Blanco-Sanchez, B.; Clement, A.; Fierro, J., Jr.; Washbourne, P.; Westerfield, M. Complexes of Usher proteins preassemble at the endoplasmic reticulum and are required for trafficking and ER homeostasis. Dis. Model Mech. 2014, 7, 547-559. [CrossRef] [PubMed]

61. Hu, J.; Li, B.; Apisa, L.; Yu, H.; Entenman, S.; Xu, M.; Stepanyan, R.; Guan, B.J.; Muller, U.; Hatzoglou, M.; et al. ER stress inhibitor attenuates hearing loss and hair cell death in Cdh23 ${ }^{\text {erl/erl }}$ mutant mice. Cell Death Dis. 2016, 7, e2485. [CrossRef] [PubMed]

62. Takeda, K.; Inoue, H.; Tanizawa, Y.; Matsuzaki, Y.; Oba, J.; Watanabe, Y.; Shinoda, K.; Oka, Y. WFS1 (wolfram syndrome 1) gene product: Predominant subcellular localization to endoplasmic reticulum in cultured cells and neuronal expression in rat brain. Hum. Mol. Genet. 2001, 10, 477-484. [CrossRef] [PubMed]

63. Fonseca, S.G.; Fukuma, M.; Lipson, K.L.; Nguyen, L.X.; Allen, J.R.; Oka, Y.; Urano, F. WFS1 is a novel component of the unfolded protein response and maintains homeostasis of the endoplasmic reticulum in pancreatic $\beta$-cells. J. Biol. Chem. 2005, 280, 39609-39615. [CrossRef] [PubMed] 
64. Fonseca, S.G.; Ishigaki, S.; Oslowski, C.M.; Lu, S.; Lipson, K.L.; Ghosh, R.; Hayashi, E.; Ishihara, H.; Oka, Y.; Permutt, M.A.; et al. Wolfram syndrome 1 gene negatively regulates er stress signaling in rodent and human cells. J. Clin. Investig. 2010, 120, 744-755. [CrossRef] [PubMed]

65. Zatyka, M.; Ricketts, C.; da Silva Xavier, G.; Minton, J.; Fenton, S.; Hofmann-Thiel, S.; Rutter, G.A.; Barrett, T.G. Sodium-potassium ATPase 1 subunit is a molecular partner of wolframin, an endoplasmic reticulum protein involved in er stress. Hum. Mol. Genet. 2008, 17, 190-200. [CrossRef] [PubMed]

66. Yurimoto, S.; Hatano, N.; Tsuchiya, M.; Kato, K.; Fujimoto, T.; Masaki, T.; Kobayashi, R.; Tokumitsu, H. Identification and characterization of wolframin, the product of the wolfram syndrome gene (WFS1), as a novel calmodulin-binding protein. Biochemistry 2009, 48, 3946-3955. [CrossRef] [PubMed]

67. Gharanei, S.; Zatyka, M.; Astuti, D.; Fenton, J.; Sik, A.; Nagy, Z.; Barrett, T.G. Vacuolar-type H $^{+}$-ATPase V1a subunit is a molecular partner of wolfram syndrome 1 (WFS1) protein, which regulates its expression and stability. Hum. Mol. Genet. 2013, 22, 203-217. [CrossRef] [PubMed]

68. Hofmann, S.; Philbrook, C.; Gerbitz, K.D.; Bauer, M.F. Wolfram syndrome: Structural and functional analyses of mutant and wild-type wolframin, the WFS1 gene product. Hum. Mol. Genet. 2003, 12, 2003-2012. [CrossRef] [PubMed]

69. Hofmann, S.; Bauer, M.F. Wolfram syndrome-associated mutations lead to instability and proteasomal degradation of wolframin. FEBS Lett. 2006, 580, 4000-4004. [CrossRef] [PubMed]

70. Ishihara, H.; Takeda, S.; Tamura, A.; Takahashi, R.; Yamaguchi, S.; Takei, D.; Yamada, T.; Inoue, H.; Soga, H.; Katagiri, H.; et al. Disruption of the WFS1 gene in mice causes progressive beta-cell loss and impaired stimulus-secretion coupling in insulin secretion. Hum. Mol. Genet. 2004, 13, 1159-1170. [CrossRef] [PubMed]

71. Yamada, T.; Ishihara, H.; Tamura, A.; Takahashi, R.; Yamaguchi, S.; Takei, D.; Tokita, A.; Satake, C.; Tashiro, F.; Katagiri, H.; et al. WFS1-deficiency increases endoplasmic reticulum stress, impairs cell cycle progression and triggers the apoptotic pathway specifically in pancreatic beta-cells. Hum. Mol. Genet. 2006, 15, 1600-1609. [CrossRef] [PubMed]

72. Bonnet Wersinger, D.; Benkafadar, N.; Jagodzinska, J.; Hamel, C.; Tanizawa, Y.; Lenaers, G.; Delettre, C. Impairment of visual function and retinal er stress activation in WFS1-deficient mice. PLoS ONE 2014, 9, e97222. [CrossRef] [PubMed]

73. Cryns, K.; Thys, S.; Van Laer, L.; Oka, Y.; Pfister, M.; Van Nassauw, L.; Smith, R.J.; Timmermans, J.P.; Van Camp, G. The WFS1 gene, responsible for low frequency sensorineural hearing loss and wolfram syndrome, is expressed in a variety of inner ear cells. Histochem. Cell Biol. 2003, 119, 247-256. [PubMed]

74. Hansen, L.; Eiberg, H.; Barrett, T.; Bek, T.; Kjaersgaard, P.; Tranebjaerg, L.; Rosenberg, T. Mutation analysis of the WFS1 gene in seven danish wolfram syndrome families; four new mutations identified. Eur. J. Hum. Genet. 2005, 13, 1275-1284. [CrossRef] [PubMed]

75. Bespalova, I.N.; Van Camp, G.; Bom, S.J.; Brown, D.J.; Cryns, K.; DeWan, A.T.; Erson, A.E.; Flothmann, K.; Kunst, H.P.; Kurnool, P.; et al. Mutations in the wolfram syndrome 1 gene (WFS1) are a common cause of low frequency sensorineural hearing loss. Hum. Mol. Genet. 2001, 10, 2501-2508. [CrossRef] [PubMed]

76. Young, T.L.; Ives, E.; Lynch, E.; Person, R.; Snook, S.; MacLaren, L.; Cater, T.; Griffin, A.; Fernandez, B.; Lee, M.K.; et al. Non-syndromic progressive hearing loss DFNA38 is caused by heterozygous missense mutation in the wolfram syndrome gene WFS1. Hum. Mol. Genet. 2001, 10, 2509-2514. [CrossRef] [PubMed]

77. Cryns, K.; Pfister, M.; Pennings, R.J.; Bom, S.J.; Flothmann, K.; Caethoven, G.; Kremer, H.; Schatteman, I.; Koln, K.A.; Toth, T.; et al. Mutations in the WFS1 gene that cause low-frequency sensorineural hearing loss are small non-inactivating mutations. Hum. Genet. 2002, 110, 389-394. [CrossRef] [PubMed]

78. Bonnycastle, L.L.; Chines, P.S.; Hara, T.; Huyghe, J.R.; Swift, A.J.; Heikinheimo, P.; Mahadevan, J.; Peltonen, S.; Huopio, H.; Nuutila, P.; et al. Autosomal dominant diabetes arising from a wolfram syndrome 1 mutation. Diabetes 2013, 62, 3943-3950. [CrossRef] [PubMed]

79. Morikawa, S.; Tajima, T.; Nakamura, A.; Ishizu, K.; Ariga, T. A novel heterozygous mutation of the WFS1 gene leading to constitutive endoplasmic reticulum stress is the cause of wolfram syndrome. Pediatr. Diabetes 2017. [CrossRef] [PubMed]

80. De Franco, E.; Flanagan, S.E.; Yagi, T.; Abreu, D.; Mahadevan, J.; Johnson, M.B.; Jones, G.; Acosta, F.; Mulaudzi, M.; Lek, N.; et al. Dominant ER stress-inducing WFS1 mutations underlie a genetic syndrome of neonatal/infancy-onset diabetes, congenital sensorineural deafness, and congenital cataracts. Diabetes 2017, 66, 2044-2053. [CrossRef] [PubMed] 
81. White, T.W.; Bruzzone, R. Multiple connexin proteins in single intercellular channels: Connexin compatibility and functional consequences. J. Bioenerg. Biomembr. 1996, 28, 339-350. [CrossRef] [PubMed]

82. Willecke, K.; Eiberger, J.; Degen, J.; Eckardt, D.; Romualdi, A.; Guldenagel, M.; Deutsch, U.; Sohl, G. Structural and functional diversity of connexin genes in the mouse and human genome. Biol. Chem. 2002, 383, 725-737. [CrossRef] [PubMed]

83. Kelsell, D.P.; Dunlop, J.; Stevens, H.P.; Lench, N.J.; Liang, J.N.; Parry, G.; Mueller, R.F.; Leigh, I.M. Connexin 26 mutations in hereditary non-syndromic sensorineural deafness. Nature 1997, 387, 80-83. [CrossRef] [PubMed]

84. Zelante, L.; Gasparini, P.; Estivill, X.; Melchionda, S.; D'Agruma, L.; Govea, N.; Mila, M.; Monica, M.D.; Lutfi, J.; Shohat, M.; et al. Connexin 26 mutations associated with the most common form of non-syndromic neurosensory autosomal recessive deafness (DFNB1) in mediterraneans. Hum. Mol. Genet. 1997, 6, 1605-1609. [CrossRef] [PubMed]

85. Denoyelle, F.; Lina-Granade, G.; Plauchu, H.; Bruzzone, R.; Chaib, H.; Levi-Acobas, F.; Weil, D.; Petit, C. Connexin 26 gene linked to a dominant deafness. Nature 1998, 393, 319-320. [CrossRef] [PubMed]

86. Estivill, X.; Fortina, P.; Surrey, S.; Rabionet, R.; Melchionda, S.; D'Agruma, L.; Mansfield, E.; Rappaport, E.; Govea, N.; Mila, M.; et al. Connexin 26 mutations in sporadic and inherited sensorineural deafness. Lancet 1998, 351, 394-398. [CrossRef]

87. Kelley, P.M.; Harris, D.J.; Comer, B.C.; Askew, J.W.; Fowler, T.; Smith, S.D.; Kimberling, W.J. Novel mutations in the connexin 26 gene (GJB2) that cause autosomal recessive (DFNB1) hearing loss. Am. J. Hum. Genet. 1998, 62, 792-799. [CrossRef] [PubMed]

88. Rabionet, R.; Zelante, L.; Lopez-Bigas, N.; D’Agruma, L.; Melchionda, S.; Restagno, G.; Arbones, M.L.; Gasparini, P.; Estivill, X. Molecular basis of childhood deafness resulting from mutations in the GJB2 (connexin 26) gene. Hum. Genet. 2000, 106, 40-44. [CrossRef] [PubMed]

89. Grifa, A.; Wagner, C.A.; D’Ambrosio, L.; Melchionda, S.; Bernardi, F.; Lopez-Bigas, N.; Rabionet, R.; Arbones, M.; Monica, M.D.; Estivill, X.; et al. Mutations in GJB6 cause nonsyndromic autosomal dominant deafness at DFNA3 locus. Nat. Genet. 1999, 23, 16-18. [PubMed]

90. Del Castillo, I.; Villamar, M.; Moreno-Pelayo, M.A.; del Castillo, F.J.; Alvarez, A.; Telleria, D.; Menendez, I.; Moreno, F. A deletion involving the connexin 30 gene in nonsyndromic hearing impairment. N. Engl. J. Med. 2002, 346, 243-249. [CrossRef] [PubMed]

91. Liu, X.Z.; Xia, X.J.; Xu, L.R.; Pandya, A.; Liang, C.Y.; Blanton, S.H.; Brown, S.D.; Steel, K.P.; Nance, W.E. Mutations in connexin 31 underlie recessive as well as dominant non-syndromic hearing loss. Hum. Mol. Genet. 2000, 9, 63-67. [CrossRef] [PubMed]

92. Yang, J.J.; Huang, S.H.; Chou, K.H.; Liao, P.J.; Su, C.C.; Li, S.Y. Identification of mutations in members of the connexin gene family as a cause of nonsyndromic deafness in taiwan. Audiol. Neuro-Otol. 2007, 12, 198-208. [CrossRef] [PubMed]

93. Huang, T.; Wan, Y.; Zhu, Y.; Fang, X.; Hiramatsu, N.; Hayakawa, K.; Paton, A.W.; Paton, J.C.; Kitamura, M.; Yao, J. Downregulation of gap junction expression and function by endoplasmic reticulum stress. J. Cell. Biochem. 2009, 107, 973-983. [CrossRef] [PubMed]

94. Allagnat, F.; Klee, P.; Cardozo, A.K.; Meda, P.; Haefliger, J.A. Connexin36 contributes to INS-1E cells survival through modulation of cytokine-induced oxidative stress, ER stress and AMPK activity. Cell Death Differ. 2013, 20, 1742-1752. [CrossRef] [PubMed]

95. Tattersall, D.; Scott, C.A.; Gray, C.; Zicha, D.; Kelsell, D.P. EKV mutant connexin 31 associated cell death is mediated by ER stress. Hum. Mol. Genet. 2009, 18, 4734-4745. [CrossRef] [PubMed]

96. Alapure, B.V.; Stull, J.K.; Firtina, Z.; Duncan, M.K. The unfolded protein response is activated in connexin 50 mutant mouse lenses. Exp. Eye Res. 2012, 102, 28-37. [CrossRef] [PubMed]

97. Berthoud, V.M.; Minogue, P.J.; Lambert, P.A.; Snabb, J.I.; Beyer, E.C. The cataract-linked mutant connexin50D47A causes endoplasmic reticulum stress in mouse lenses. J. Biol. Chem. 2016, 291, 17569-17578. [CrossRef] [PubMed]

98. Zhang, Y.; Wang, J.; Li, L.; Sun, Y.; Feng, B. Three common GJB2 mutations causing nonsyndromic hearing loss in Chinese populations are retained in the endoplasmic reticulum. Acta Oto-Laryngol. 2010, 130, 799-803. [CrossRef] [PubMed]

99. Hong, H.M.; Yang, J.J.; Su, C.C.; Chang, J.Y.; Li, T.C.; Li, S.Y. A novel mutation in the connexin 29 gene may contribute to nonsyndromic hearing loss. Hum. Genet. 2010, 127, 191-199. [CrossRef] [PubMed] 
100. Wong, S.H.; Wang, W.H.; Chen, P.H.; Li, S.Y.; Yang, J.J. Functional analysis of a nonsyndromic hearing loss-associated mutation in the transmembrane II domain of the GJC3 gene. Int. J. Med. Sci. 2017, 14, $246-256$. [CrossRef] [PubMed]

101. Xia, K.; Ma, H.; Xiong, H.; Pan, Q.; Huang, L.; Wang, D.; Zhang, Z. Trafficking abnormality and ER stress underlie functional deficiency of hearing impairment-associated connexin-31 mutants. Protein Cell 2010, 1, 935-943. [CrossRef] [PubMed]

102. Berger, A.C.; Kelly, J.J.; Lajoie, P.; Shao, Q.; Laird, D.W. Mutations in CX30 that are linked to skin disease and non-syndromic hearing loss exhibit several distinct cellular pathologies. J. Cell Sci. 2014, 127, 1751-1764. [CrossRef] [PubMed]

103. Boughman, J.A.; Vernon, M.; Shaver, K.A. Usher syndrome: Definition and estimate of prevalence from two high-risk populations. J. Chronic Dis. 1983, 36, 595-603. [CrossRef]

104. Mathur, P.; Yang, J. Usher syndrome: Hearing loss, retinal degeneration and associated abnormalities. Biochim. Biophys. Acta 2015, 1852, 406-420. [CrossRef] [PubMed]

105. Isosomppi, J.; Vastinsalo, H.; Geller, S.F.; Heon, E.; Flannery, J.G.; Sankila, E.M. Disease-causing mutations in the CLRN1 gene alter normal CLRN1 protein trafficking to the plasma membrane. Mol. Vis. 2009, 15, 1806-1818. [PubMed]

106. Han, F.; Yu, H.; Tian, C.; Chen, H.E.; Benedict-Alderfer, C.; Zheng, Y.; Wang, Q.; Han, X.; Zheng, Q.Y. A new mouse mutant of the Cdh23 gene with early-onset hearing loss facilitates evaluation of otoprotection drugs. Pharmacogenom. J. 2012, 12, 30-44. [CrossRef] [PubMed]

107. Yamasoba, T.; Lin, F.R.; Someya, S.; Kashio, A.; Sakamoto, T.; Kondo, K. Current concepts in age-related hearing loss: Epidemiology and mechanistic pathways. Hear. Res. 2013, 303, 30-38. [CrossRef] [PubMed]

108. Yang, C.H.; Schrepfer, T.; Schacht, J. Age-related hearing impairment and the triad of acquired hearing loss. Front. Cell. Neurosci. 2015, 9, 276. [CrossRef] [PubMed]

109. Le, T.N.; Straatman, L.V.; Lea, J.; Westerberg, B. Current insights in noise-induced hearing loss: A literature review of the underlying mechanism, pathophysiology, asymmetry, and management options. J. Otolaryngol. Head Neck Surg. 2017, 46, 41. [CrossRef] [PubMed]

110. Kalinec, G.M.; Lomberk, G.; Urrutia, R.A.; Kalinec, F. Resolution of cochlear inflammation: Novel target for preventing or ameliorating drug-, noise- and age-related hearing loss. Front. Cell. Neurosci. 2017, 11, 192. [CrossRef] [PubMed]

111. Shearer, A.E.; Hildebrand, M.S.; Smith, R.J.H. Hereditary hearing loss and deafness overview. In GeneReviews ${ }^{\circledR}$ [Internet]; Adam, M.P., Ardinger, H.H., Pagon, R.A., Wallace, S.E., Bean, L.J.H., Mefford, H.C., Stephens, K., Amemiya, A., Ledbetter, N., Eds.; University of Washington: Seattle, WA, USA, 1993-2017. 